\title{
Interculturalism and Teaching Music in Grammar Schools
}

\author{
Amir Begić ${ }^{1}$, Jasna Šulentić Begić ${ }^{1}$, Ivana Pušić ${ }^{1}$ \\ ${ }^{1}$ Academy of Arts in Osijek, Croatia \\ Correspondence: Amir Begić, Academy of Arts in Osijek, Croatia. \\ Received: January 12, 2017 \\ Accepted: February 8, 2017 \\ Online Published: February 9, 2017 \\ doi:10.11114/jets.v5i3.2188 \\ URL: http://dx.doi.org/10.11114/jets.v5i3.2188
}

\begin{abstract}
The concept of intercultural education should be aimed at better understanding of ourselves and others, discovering similarities and differences, recognizing preconceptions, and cooperation in accomplishing our common goals. Intercultural education can be very useful in resolving the issues that arise when different groups live together. Also, intercultural education may benefit the process of getting to know and better understand other cultures and the development of successful communication between cultures. Music courses in grammar schools may contribute to students' intercultural education, because music is an area in which cultural competence can develop significantly. During the December of 2014, for the purposes of this paper, a research study was conducted in a Croatian general programme grammar school. The goal of the study was to determine the students' attitudes toward interculturalism, their attitudes on music courses with regard to interculturalism, and are there any differences in the attitudes and intercultural awareness between first grade students and fourth grade students at the grammar school. A survey questionnaire was used to conduct an anonymous survey among first and fourth grade students. The results of the study have shown that both the first and fourth grade students are aware that they are living in a multicultural environment, as well as that there are examples of certain forms of intolerance towards members of other cultures who share their living surroundings. When compared to fourth grade students, first grade students generally have more positive attitudes toward interculturalism. According to the students' opinions, music courses at the grammar school could be more focused on getting to know the music and musical traditions of the people from other continents. Complementing the syllabus with music from different cultures and from all the continents would contribute to the development of more positive students' attitudes toward interculturalism and help with the realization of goals set by the premise of intercultural education.
\end{abstract}

Keywords: music courses, grammar school, intercultural education, students

\section{Intercultural Education and Music Courses}

With the arrival of students from different cultural backgrounds, the school system faced one of the most important changes in its history, which was marked by the transition from the uniform mono-cultural and single nation environment into the plural cultural environment (Hrvatić \& Piršl, 2007). That is why intercultural education is necessary for students, it provides the students with intercultural competence, which contributes to the quality of education and the school atmosphere, reduces ethnocentrism, preconceptions, stereotypes, inequality, and discrimination in the society (Piršl, 2007). The National Curriculum Framework (2010), in the part regarding education on humanities and social sciences, states that the students will:

- develop communication, organisational and social skills, as well as adopt intercultural competences that will enable them to understand and accept other, different people, regardless of their gender or their cultural, social, racial, religious, national, or ethnic background

- differentiate between personal identity and other identities, and recognise the multiple identities inherent in individuals

- preserve their heritage and demonstrate an appropriate attitude towards the Croatian cultural heritage and country, as well as other cultures, and cultural heritage of Europe and the world.

A modern school curriculum should articulate content, programmes, and teaching methods and procedures that will be related not only to acquiring knowledge, but also, by observing the world from various philosophical angles and positions, deconstruct various social stereotypes, preconceptions, and stigmatisation among people through direct interaction (Previšić, 2004). The issue of intercultural education and acquiring intercultural competences is becoming 
increasingly important in the recent years, with the appearance of globalization and global contacts between large companies, organizations, but also individuals, all of which cannot be imagined without successful communication. Sensitivity and self-awareness, or rather understanding the behaviour of others and the way they think and perceive the world, along with successful communication, are becoming the basic requirements of intercultural competence (Hrvatic \& Piršl, 2007).

A crucial component of multicultural education is a concept according to which all students, regardless of their gender, nation, race, culture, language, social class, religion... are entitled to equal treatment when it comes to education (Banks \& Banks, 2007, according to Coalson, 2011). Many claim that introducing the elements of interculturalism in multicultural communities is particularly important because it leads to the development of respect for cultural diversity, with the ultimate goal of developing students' respect toward various cultures (Izgarjan et al., 2013). Considering that societies are becoming increasingly pluralistic and global, acquiring the ability to understand other cultures is becoming more and more important... (Landis \& Brislin, 1983 according to Neto, 2006). These are just the types of intercultural competences acquired through intercultural education, and that can largely be accomplished as part of music courses.

Since the beginnings of music until today, many nations and various cultures were a part of its development. Music courses in grammar schools should encompass the entirety of the development of music, as much as possible, as well as introducing as many musical traditions from around the world as possible. Music Education courses in Croatian general programme grammar schools consist of 140 classes (over the span of four years); while grammar schools with science and mathematics focused programmes are implementing two year music education courses, consisting of 70 classes. During those courses the students are introduced to music and musical traditions of many nations. It is quite clear that with such limited time it is impossible to convey the entirety of the history of music, only the "most important" information is included. However, when deciding on what the "most important" information is, music from those nations and cultures not sufficiently familiar to us, or "far away" (geographically or culturally) from us, is often overlooked.

Music courses in grammar schools are mostly oriented toward listening to compositions, where the works of Croatian authors are greatly represented (which is of course completely justified), because developing awareness of one's own cultural identity is a key factor and a necessary precondition for intercultural considerations and actions of individuals (Mueller \& Pope, 2003). When listening to music from other nations we are becoming more familiar with their culture (Šulentić Begić, 2010), but also, when learning about our own culture we are developing awareness about our own cultural identity, which contributes to the development of intercultural competences. However, listening to music as part of music courses includes even more compositions from musical traditions of other nations (primarily European). But despite the traditional orientation of Croatian music (and consequently music courses) toward Western European musical heritage, the current globalization, and the development of communication technologies and media, as well as migration trends and multicultural societies, are creating the need to become better acquainted with cultures of nations from other continents.

Research studies conducted by some authors have examined the attitudes of students regarding interculturalism. Neto (2006) states that at the cognitive level, attitudes regarding interculturalism are helping to organize the world around us by immediately making sense of the numerous impulses received from other people (e.g. through direct contact) or indirectly (for example through the media). At the sociological level, intercultural attitudes help us organize the world around us by making sense of the many differences and inequalities that surround us (e.g. lower financial means of some minorities) (ibid. 2006). Goroshit, Hen \& Kraus (2013) concluded that members of majority cultures have positive attitudes toward interculturalism, but when it comes to attitudes toward specific groups, those attitudes become less positive. On the other hand, members of minority cultures also ideologically support interculturalism, but are more focused on the practical implementation of interculturalism, and especially when it concerns their own group.

Even though many studies provide evidence on the efficiency of intercultural education, research investigating the efficiency of specific teaching strategies for intercultural education is still insufficient (Dickson \& Shumway, 2011). Same could also be said about research regarding the attitudes of grammar school students about interculturalism in music courses. Research dealing with the issue of interculturalism and teaching music is mostly focused on the success and the methods for acquiring intercultural competences by future music teachers. On that note, e.g. Joseph \& Southcott (2010) emphasise that students should be encouraged to develop intercultural competences that will be necessary for their educational work in the future. Also, some authors have studied the attitudes of secondary school students on multiculturalism in general. Buterin \& Jagić (2013) concluded that secondary school students have moderately positive attitudes toward members of other (minority) cultures. However, no research was conducted on the attitudes of grammar school students toward music courses and the music courses themselves with regards to multiculturalism. This area has not been sufficiently explored, in Croatia or elsewhere. That is why the goal of this paper was to recognize the attitudes of students toward interculturalism in general, but also toward music courses as the medium for realizing that 
interculturalism, and as the area where the necessary competences could be acquired.

\section{Method}

During the December of 2014, for the purposes of this paper, a research study was conducted in a Croatian general programme grammar school. Grammar school programmes in Croatia enable students to acquire extensive general education knowledge, which is an excellent basis for continuing education in higher education institutions. In grammar school (except mathematical gymnasium) the music subject is part of the curriculum in the four year period (one hour per week). The goal of the study was to determine the students' attitudes toward interculturalism, their attitudes on music courses with regard to interculturalism, and are there any differences in the attitudes and intercultural awareness between first grade students and fourth grade students at the grammar school. The research study participants were first grade students $(\mathrm{N}=147$; 14-15-year-old) and fourth grade students $(\mathrm{N}=139 ; 17-18$-year-old). Their attitudes on interculturalism and grammar school music courses were examined using an anonymous survey study questionnaire.

The survey study questionnaire contained fifteen statements that the students were asked to evaluate according to a Likert scale with number values from 1 to 5 , where the numbers had the following meanings: 1 -I completely disagree; 2 -I mostly disagree; 3 -I neither agree nor disagree; 4 -I mostly agree; 5 -I completely agree. The number value 1 designates complete disagreement, while the number value 5 designates complete agreement, which means that disagreement will be higher if the arithmetic mean is lower, and consequently, if the arithmetic mean is higher, the level of agreement will be higher. Quantitative approach was used for processing data, and descriptive statistics, as well as the $t$-test, were applied to the independent samples used for determining a statistically significant difference between two independent groups of study participants (in this case, first and fourth grade students in the grammar school).

\section{Results and Discussion}

The data interpretation part of this paper will include graphical displays of arithmetic means calculated on the basis of some of the replies from first or fourth grade students.

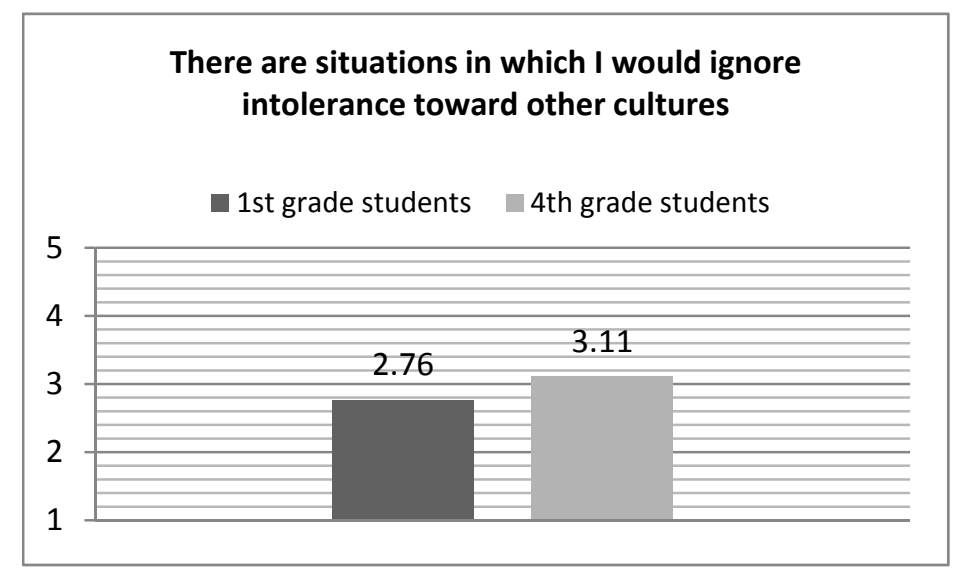

Figure 1. Ignoring intolerance

Regarding the claim that there are situations in which they would ignore intolerance toward members of other cultures, first and fourth grade students took a mostly neutral position. However, somewhat higher level of disagreement with this statement can be seen for first grade students. 


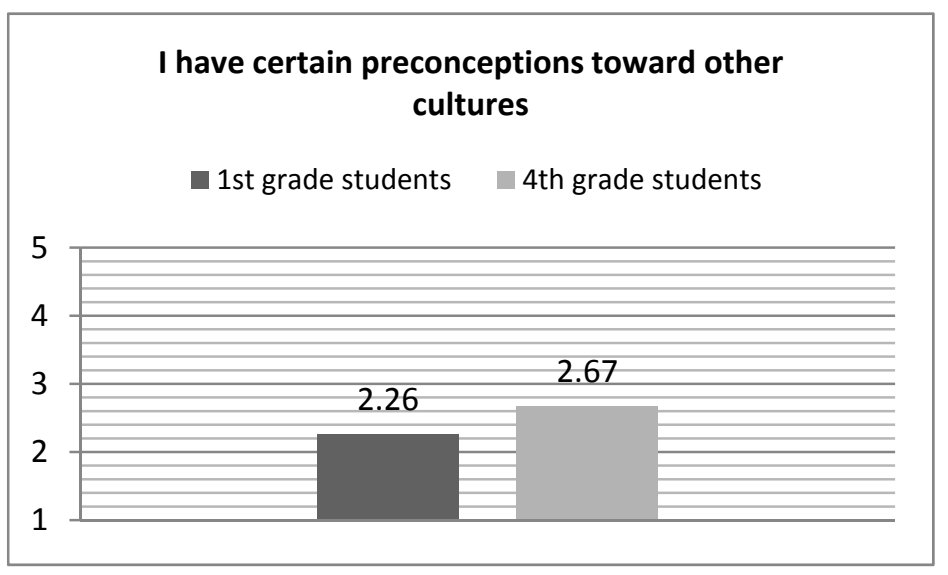

Figure 2. Preconceptions about other cultures

First grade students mostly disagreed with the statement that they have preconceptions about other cultures, while in this case fourth grade students were closer to the neutral position.

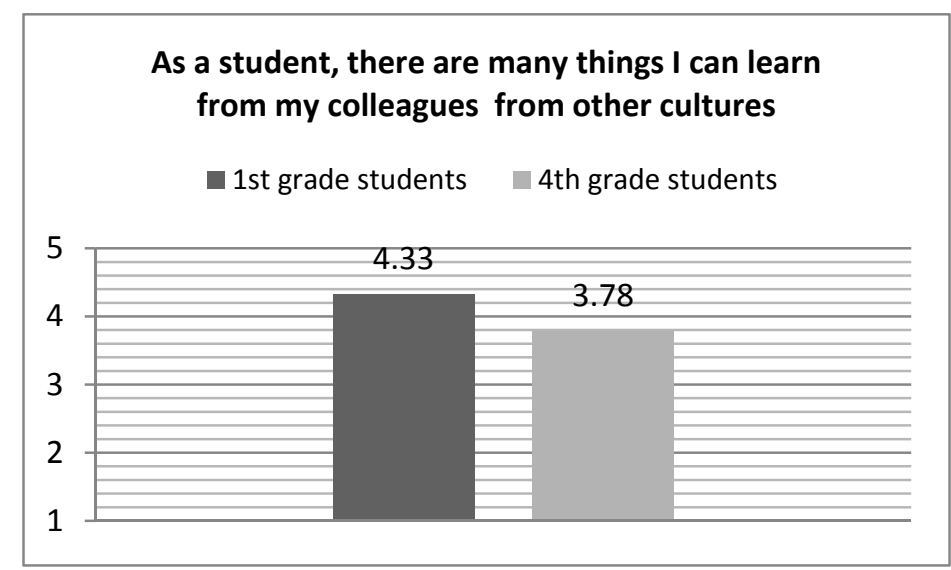

Figure 3. Different cultures as a source of new experiences and knowledge

The level of agreement regarding the statement that they have much to learn from their colleagues from other cultures was very high for first grade students. The level of agreement regarding the same statement was lower for fourth grade students.

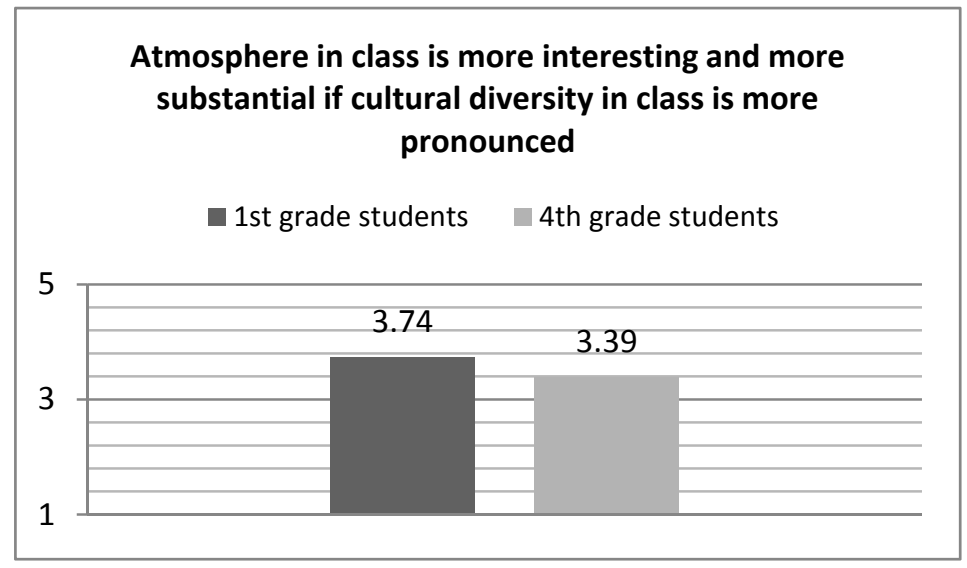

Figure 4. Atmosphere in a multicultural class

The next statement was: Atmosphere in class is more interesting and more substantial if cultural diversity in class is more pronounced. First grade students mostly agreed with this statement. Fourth grade students displayed a somewhat higher level of disagreement in this case. 


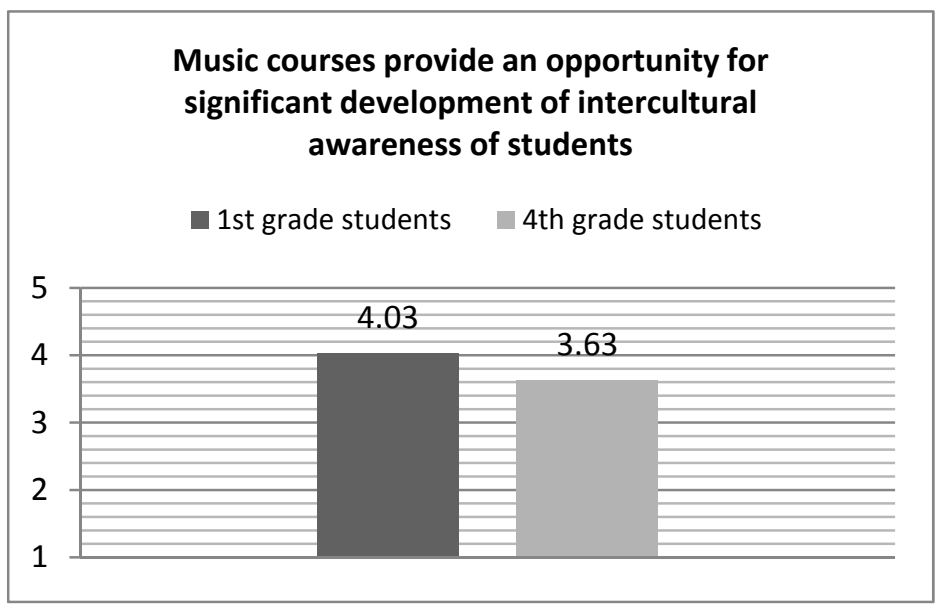

Figure 5. Music courses as a source for acquiring intercultural competences for students

The next statement was: Music courses provide an opportunity for significant development of intercultural awareness of students. The level of agreement regarding this statement was very high for first grade students. The level of agreement was lower for fourth grade students.

It is visible from the shown arithmetic means that there are differences in attitudes between first and fourth grade students regarding interculturalism. The significance of those differences was examined using a $t$-test (Table 1).

Table 1. Differences in attitudes of first and fourth grade students

\begin{tabular}{|c|c|c|c|c|c|c|c|}
\hline \multirow[b]{2}{*}{ No. } & \multirow[b]{2}{*}{ STATEMENT } & \multicolumn{2}{|c|}{$1^{\text {st }}$ grade } & \multicolumn{2}{|c|}{$4^{\text {th }}$ grade } & \multicolumn{2}{|c|}{$\mathrm{df}=284, \operatorname{tg}=1.96$} \\
\hline & & $\mathrm{AM}$ & SD & $\mathrm{AM}$ & SD & $t$-test & $\mathrm{p}$ \\
\hline 1 & I am aware that I am living in a multicultural environment. & 4.25 & 0.86 & 4.12 & 0.98 & 1.30 & 0.2061 \\
\hline 2 & $\begin{array}{l}\text { I am aware that there is intolerance toward members of other cultures around } \\
\text { me. }\end{array}$ & 4.01 & 1.13 & 3.96 & 0.92 & 0.42 & 0.6392 \\
\hline 3 & There are situations in which I would ignore intolerance toward other cultures. & 2.76 & 1.20 & 3.11 & 1.09 & 2.69 & $0.0448 *$ \\
\hline 4 & I have certain preconceptions toward other cultures. & 2.26 & 1.41 & 2.67 & 1.36 & 2.93 & $0.0361 *$ \\
\hline 5 & $\begin{array}{l}\text { Knowledge about other cultures is a precondition for better understanding the } \\
\text { differences between students. }\end{array}$ & 4.34 & 1.07 & 4.05 & 0.97 & 2.42 & 0.0579 \\
\hline 6 & $\begin{array}{l}\text { As a student, there are many things I can learn from my colleagues from other } \\
\text { cultures. }\end{array}$ & 4.33 & 0.97 & 3.78 & 1.08 & 4.58 & $0.0109 *$ \\
\hline 7 & $\begin{array}{l}\text { The teacher must recognise the needs of students from cultures different than } \\
\text { the culture of the remaining students in class. }\end{array}$ & 3.65 & 1.32 & 3.59 & 1.17 & 0.40 & 0.6547 \\
\hline 8 & $\begin{array}{l}\text { Atmosphere in class is more interesting and more substantial if cultural } \\
\text { diversity in class is more pronounced. }\end{array}$ & 3.74 & 1.24 & 3.39 & 1.07 & 2.69 & $0.0448 *$ \\
\hline 9 & I feel uncomfortable around people from different cultures. & 1.82 & 1.15 & 1.75 & 0.89 & 0.54 & 0.5519 \\
\hline 10 & $\begin{array}{l}\text { In my future profession I would like to work with colleagues from other } \\
\text { cultures. }\end{array}$ & 3.69 & 1.14 & 3.44 & 1.07 & 1.92 & 0.0980 \\
\hline 11 & $\begin{array}{l}\text { Music courses provide an opportunity for significant development of tolerance } \\
\text { and respect for other cultures. }\end{array}$ & 4.03 & 0.95 & 3.63 & 0.94 & 3.64 & $0.0204 *$ \\
\hline 12 & We are learning enough about European music as part of our music courses. & 4.14 & 1.00 & 4.02 & 0.66 & 1.20 & 0.2343 \\
\hline 13 & $\begin{array}{l}\text { Music courses should include more listening and more information about } \\
\text { music from other continents. }\end{array}$ & 3.86 & 1.08 & 3.59 & 1.17 & 2.08 & 0.0823 \\
\hline 14 & $\begin{array}{l}\text { The music teacher should promote cultural diversity and understanding } \\
\text { through listening to compositions and singing songs from other cultures. }\end{array}$ & 3.97 & 1.11 & 3.76 & 0.95 & 1.75 & 0.1190 \\
\hline 15 & $\begin{array}{l}\text { Knowledge about music from other cultures strengthens our awareness about } \\
\text { the significance of musical tradition of our own people and our national } \\
\text { identity. }\end{array}$ & 4.14 & 1.09 & 3.89 & 0.87 & 2.27 & 0.0674 \\
\hline
\end{tabular}

${ }^{*} \mathrm{p}<0.05$

It is evident from these results that there are significant differences in answers from first and fourth grade students to five statements in total $(3,4,6,8$, and 11). The differences in all five answers indicate more positive attitudes of first grade students regarding interculturalism and the greater level of understanding for different cultures and members of those cultures. The most significant difference is regarding ignoring intolerance $(\mathrm{t}=2.69, \mathrm{p}<0.05)$, preconceptions about other cultures $(t=2.93, p<0.05)$, accepting other cultures as sources of new experiences and knowledge $(t=4.58, p<0.05)$, interculturalism in class $(\mathrm{t}=2.69, \mathrm{p}<0.05)$, andmusic courses as a source for acquiring intercultural competences for students $(\mathrm{t}=3.64, \mathrm{p}<0.05)$. The difference is less significant for other answers, but greatly in favour of first grade students (aside from statement number 9). Buterin \& Jagić (2013) and Blažević Simić (2011) determined in their 
research that students in lower grades of secondary school have attitudes that are more negative towards minorities than older students. Our research has yielded completely different results, i.e. it shows that first grade students are somewhat more tolerant toward other cultures when compared to students in the final grade of grammar school (it is important to mention here that the mentioned researchers examined students from various secondary schools, and this research study focused only on grammar school students). The possible cause for that is the fact that younger students were not in the position to be exposed to negative influences (from the media or their social circle) and that this resulted in their somewhat more tolerant attitudes than those of their older colleagues, who were more exposed to those influences.

When comparing the results of this study and the study implemented with a sample consisting of music students from one of the faculties in Croatia, there is a significant difference in more positive attitudes toward interculturalism and music courses as an area where interculturalism can be developed,in favour of university students as opposed to grammar school students. The results of that study have shown that music students have considerably higher awareness of the fact that they live in a multicultural environment and that they understand the importance of intercultural awareness (Begić, 2014). In view of the fact that the university students have acquired their intercultural competences mostly through music courses, this raises the question about whether there could be any progress in intercultural education through creating custom content for the course Music Education in grammar schools.

\section{Conclusion}

Music courses in grammar schools provide plenty of space for implementing and realising intercultural education. Realising that goal is only possible through an intercultural approach which must include knowledge and understanding of musical traditions of people from different cultures. By appreciating and recognising various musical styles, the students will be simultaneously developing cultural understanding and tolerance towards others. This is the actual purpose of intercultural education that can be implemented through music courses because... music is essentially a multicultural art (Šulentić Begić, 2010). As part of Music Education courses, students become more familiar with their own tradition and culture, but also with European tradition and culture, and, to a lesser extent, with the tradition and culture of people from other continents. However, by listening to music created by people from other continents, getting to know their traditions and customs, which are often significantly different to our own (and European), and talking about these cultures, the students will find out about something new, different, and interesting. This is the path toward accepting diversity, recognising the features that make everyone special, and consequently developing intercultural competences necessary to successfully function and live in a multicultural world.

The goal of this research study was to determine if there are any differences in attitudes between first grade and fourth grade grammar school students toward interculturalism in general, as well as their attitudes toward music courses as a place for realising the goals of intercultural education. Grammar school students included in the research have expressed moderately positive to positive attitudes toward multiculturalism. They are also aware that they live in a multicultural environment and that there are certain forms of intolerance toward members of other cultures in the environment that they live in. Another conclusion that was reached is that first grade students, when compared to fourth grade students and observing them as a group, are expressing more positive attitudes toward interculturalism. Music Education courses in grammar school, according to the students' opinions, could include more information about musical culture and tradition of people from other continents. In other words, aside from Western European musical tradition, the students should be educated about music from different cultures (e.g. African, Asian, Australian, South American...).

Complementing the course syllabi with music from different cultures and from all continents would contribute to the development of more positive attitudes of grammar school students toward interculturalism and help with the realisation of goals of intercultural education. We suggest further research that would help with the possibilities for creating new teaching content on the topic.

\section{References}

Begić, A. (2014). Intercultural competencies of music teacher education students. In: Artists as Pedagogues Facing the Challenges of Contemporary Education, (Editor Škojo, T.), Osijek: Josip Juraj Strossmayer University of Osijek, Academy of Arts in Osijek, 81-95.

Blažević Simić, A. (2011). Social Distance of Croatian Secondary School Students towards Ethnic and Religious Groups. Pedagogijska istraživanja, 8(1), 153-170. Retrieved from http://hrcak.srce.hr/118074

Buterin, M., \& Jagić, S. (2013). Attitudes of Croatian high school students to minority groups. Informatologia, 46(4), 322-332. Retrieved from http://hrcak.srce.hr/113092

Coalson, K. (2011). Relationships among Multicultural Educational Practices, Student Self-Efficacy, and Student Cultural Identity in the High School Setting. Digital Commons and East Tennessee State University. 
Undergraduate Honors Theses. http://dc.etsu.edu/cgi/viewcontent.cgi?article=1155\&context=honors

Dickson, G. L., \& Shumway, B. A., (2011). A framework of multifaceted training approaches to multicultural training. Vistas. https://www.counseling.org/docs/default-source/vistas/vistas_2011_article_69.pdf?sfvrsn=11

Goroshit, M., Hen, M., \& Kraus, E. (2013). Arab and Jewish Students' Attitudes towards Multiculturalism in Israel: The Moderating Role of Ethnic Identity. Mediterranean Journal of Social Sciences, 14(4), 303-309. https://doi.org/10.5901/mjss.2013.v4n14p303

Hrvatić, N., \& Piršl, E. (2007). Intercultural competence of teacher. In: Competences and teacher competence (Editor Babić, N.), Osijek: Josip Juraj Strossmayer University of Osijek, Faculty of Education in Osijek (Croatia), Kherson State University (Ukraine), 221-228. https://bib.irb.hr/prikazi-rad?\&rad=673928

Izgarjan, A., Markov, S., \& Prodanović-Stankić, D., (2013). Gender and Politics as the Dominant Factors in the Perceptions of Multicultural Education. Gender Studies, The Journal of West University, Timisoara, Interdisciplinary Centre for Gender Studies, 12(1), 333-360. https://doi.org/10.2478/genst-2013-0021

Joseph, D., \& Southcott, J. (2010). Experiences and understandings: student teachers' beliefs about multicultural practice in music education. Australian journal of music education, 2, 66-75. http://files.eric.ed.gov/fulltext/EJ916791.pdf

Mueller, J. A., \& Pope, R. L. (2003). The Relationship of Demographic and Experience Variables to White Racial Consciousness Among Student Affairs Practitioners. NASPA Journal, 40(4), 149-171. https://doi.org/10.2202/0027-6014.1285

National Curriculum Framework (2010). Zagreb: Ministry of Science and Education of the Republic of Croatia. Retrieved from http://www.azoo.hr/images/stories/dokumenti/Nacionalni_okvirni_kurikulum.pdf

Neto, F. (2006).Changing intercultural attitudes over time. Journal of Intercultural Communication. Retrieved from http://www.immi.se/intercultural

Piršl, E. (2007). Intercultural sensibility as a part of pedagogic competence. In: Pedagogy: Towards Lifelong Learning and Knowledge Society (Editor Previšić, V., Šoljan, N., Hrvatić, N.), Zagreb: Croatian pedagogical society, 275-291.Retrieved from https://bib.irb.hr/prikazi-rad?\&rad=673981

Previšić, V. (2004). Intercultural attitudes of croatian grammar school students. Pedagogijska istraživanja, 1(1), 23-24. Retrieved from http://hrcak.srce.hr/139370

Šulentić Begić, J. (2010). Music and interculturalism. In: Proceedeings of the 2nd International Scientific Conference Intercultural Education (Editor Peko, A., Sablić, M., Jindra, R.), Osijek: Josip Juraj Strossmayer University of Osijek, Faculty of Education in Osijek, 327-340.

Vassallo, B. (2012). Am I Culturally Competent? A study on Multicultural Teaching Competencies among School Teachers in Malta. The Journal of Multiculturalism in Education, 8(1),

https://www.wtamu.edu/journal/volume-8-number-3.aspx\#11

\section{Copyrights}

Copyright for this article is retained by the author(s), with first publication rights granted to the journal.

This is an open-access article distributed under the terms and conditions of the Creative Commons Attribution license which permits unrestricted use, distribution, and reproduction in any medium, provided the original work is properly cited. 